\title{
Assessment of Moringa oleifera Seeds as a Natural Coagulant in Treating Low Turbid Water
}

\author{
*Taiwo O. Olabanji, Ochuko M. Ojo, Charles G. Williams and Abiodun S. Adewuyi \\ Department of Civil and Environmental Engineering, Federal University of Technology, Akure, Nigeria \\ oreoluwataiwo27@gmail.com | \{omojo | williamscg |\}@futa.edu.ng | adew.steve@gmail.com
}

ORIGINAL RESEARCH ARTICLE

Received: 29-SEP-2021; Reviewed: 13-NOV-2021; Accepted: 20-DEC-2021

http://dx.doi.org/10.46792/fuoyejet.v6i4.702

\begin{abstract}
This research examined the coagulating potential of Moringa oleifera seeds in treating low turbid water. The active ingredient of the seeds was extracted using Soxhlet Apparatus with hexane as the solvent, after which the coagulant was dosed from $0.03 \mathrm{~g} / \mathrm{L}$ to $0.4 \mathrm{~g} / \mathrm{L}$ and used to treat a water sample with a low Turbidity of $18.4 \mathrm{NTU}$, yielding an optimum value of $4.90 \mathrm{NTU}$, an optimum dose of $0.03 \mathrm{~g} / \mathrm{L}$ and a turbidity reduction of $100 \%$ when compared with the World Health Organization (WHO) standard which is 5 NTU. The study affirms Moringa oleifera as an effective natural coagulant in low turbid water treatment and it is recommended for household water treatments.
\end{abstract}

Keywords- Hexane, Low turbid water, Moringa oleifera, Natural coagulant, Soxhlet apparatus

\section{INTRODUCTION}

$\mathrm{W}$ ater is essential for all living things to survive. As a result, humans sought to settle near sources of freshwater. The world's population has grown by multiple orders of magnitude over time, but freshwater supply has stayed steady, putting an increasing strain on it. (Jain, 2010). Water quality deteriorates dramatically as a result of contamination induced by geometric population expansion, domestic and agricultural activities, modern industrialization, culture, and other geological, environmental, and geographical shifts. (Gidde, 2011). Water treatment entails a combination of processes based on quality of the water source, such as turbidity and quantity of microbial load present in the water, as well as cost and chemical availability, to achieve the required level of treatment. (Muyibi et al., 2009).

Suspended particles, such as clay, silt, finely divided organic and inorganic matter, soluble colored organic compounds, plankton, and other microscopic animals, generate turbidity in water. (Environmental Protection Agency, 2001), while Organic matter and inorganic salts which can come from sewage, effluent discharge and urban runoff as well as natural bicarbonates, chlorides, sulphate, nitrate, sodium, potassium, calcium and magnesium, make up total dissolved solids (World Health Organization, 2006). Purification methods such as coagulation, sedimentation, filtration, aeration and chemical treatment are useful techniques for water purification. The coagulation process is often used in water treatment to dislodge suspended particles and react with organic components in raw water, both of which are necessary for an effective disinfection and filtering process to occur (Moramudaii and Fernando, 2001).

\section{${ }^{*}$ Corresponding Author}

Section E- CIVIL ENGINEERING \& RELATED SCIENCES

Can be cited as:

Olabanji T.O., Ojo O.M., Williams C.G. and Adewuyi A.S. (2021): Assessment of Moringa oleifera Seeds as a Natural Coagulant in Treating Low Turbid Water, FUOYE Journal of Engineering and Technology (FUOYEJET), 6(4), 397-400. http://dx.doi.org/10.46792/fuoyejet.v6i4.702
Compounds of Aluminium and Iron from sulphur and chlorine are widely used chemical coagulants (Mbaeze et al., 2017). Owing to the excessive addition of chemicalbased coagulants influencing human health, maximum doses of these chemical coagulants should be identified (Malla et al., 2014). Iron residue in water induces excessive blood iron that kills cells and results in Alzheimer's disease (Leiw et al., 2006). Also, the use of chemical coagulants for water purification restricts the financial resources of most developing countries as they are imported to make treated water costly (Amagloh and Benang 2009). The discovery of other safe coagulants is needed to establish a cost-effective, environmentally safe, and more straightforward water clarification process. Many researchers have found natural coagulants to substitute chemical coagulants, and some extracts obtained from plants have shown an excellent water coagulation result (Nayana \& Veena, 2019). In recent years, certain studies have been performed on natural coagulants such as Cactus latifaria, Moringa oleifera and Prosopis juliflora (Akshaya et al., 2012).

Natural coagulants possess many remarkable characteristics over chemical coagulants. Some of these characteristics are; they can be grown locally, and as such they are cost-effective in developing countries, they also generate considerably less sludge, human-safe, naturally degradable, can be possibly used at various doses to flocculate different colloidal suspensions (Raji et al., 2015). Moringa oleifera is a versatile tropical tree whose seeds contain high quality edible oil (up to $40 \%$ by weight) and water-soluble proteins that operate as excellent coagulants in water and waste water treatment (Bhuptawat et al., 2007). It is not recommended to keep water treated with crude Moringa oleifera extract for more than 24 hours because of the oil content (Jahn, 1988). Therefore, it is not suitable to use the crude extract from Moringa oleifera to treat large water supply systems with a long hydraulic residence time. Oil can be extracted from the seeds to the coagulant and eatable oil as by product (Ali et al., 2010). Sometimes, contaminants are present in small quantities; forming a low turbid water, which makes the water appear pure to the naked eyes, but could be harmful to their health if the water is consumed in its 
raw form. This research aims at extracting oil from Moringa oleifera seeds so as to improve the quality of the coagulant thereby increasing the storage time of the treated water and also to investigate the effectiveness of Moringa oleifera in improving the quality of low-turbid water.

\section{Materials and Methods \\ 2.1 SOURCE, DESCRIPTION AND PREPARATION OF THE COAGULANT}

Dry and mature seeds of Moringa oleifera (MO) were handpicked from MO trees in Oke - Aro, Akure, Ondo state. All seeds were prepared for use by manually sorting out the bad ones and then removing the seed shells to get the kernels. Only the brown seeds were used in the experiment because they have a higher coagulation ability than the green pods, which have no coagulation properties (Tunggolou and Payus, 2017). The kernels gotten from the seed was ground into powder using heavy duty grinding machine at the major market in Akure, Ondo state, and then sieved through the $600 \mu \mathrm{m}$ sieve. The fine powder obtained from this process was then packed into an air-tight container.

Similar to the procedure employed by Muyibi et al. (2003), the use of the electrothermal Soxhlet apparatus was employed for the oil extraction process, and the procedure is as follows:

i. $10 \mathrm{gm}$ of the powdered seed was weighed and set into the thimbles of the electrothermal Soxhlet extraction chamber;

ii. $170 \mathrm{ml}$ of Hexane was poured into the heating chamber;

iii. The oil was extracted from the seeds as the hexane was passed through the thimbles in cycles till it became colourless;

iv. The residue obtained from the Soxhlet thimbles was dried and weighed;

v. The dried sample was used as the coagulant.

\subsection{RAW WATER Collection}

The raw water sample used in this study was obtained from downstream of the Ala River, located in Akure Ondo

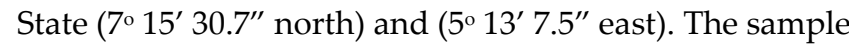
bottles used for sample collection and analysis were obtained from the market and washed with distilled water and then dried. The raw water was gotten from the river into the sample bottle and immediately transported to the laboratory for treatment and analysis.

\subsection{Coagulation/ Flocculation Process Using a MAGNETIC STIRRING MACHINE}

Different weights (ranging from $0.03 \mathrm{~g}-0.4 \mathrm{~g}$ ) of the obtained coagulant was added to $250 \mathrm{ml}$ of the water sample in six different beakers and then the beakers were placed on the magnetic stirring machine, one beaker at a time. The machine was set at about $120 \mathrm{rpm}$ for rapid mixing for 30 secs and 50rpm for 8 mins for slow agitation (Ezeh et al., 2017). The samples were filtered using a filter paper and the filtered samples were kept in labelled $100 \mathrm{ml}$ bottles.

\subsection{LABORATORY ANALYSIS}

The tests carried out on the raw water and treated water samples are as follows: Turbidity test was done using a Lovibond Water Test TB 210 IR Turbidimeter. Total Dissolved Solids (TDS) and Conductivity were measured using Hanna HI9813-6 pH meter and Dissolved Oxygen (DO) using Hanna HI 3810 DO test kit.

\section{Results ANd Discussion}

The raw water gotten from Ala River in Akure, Ondo state had a Turbidity of $18.4 \mathrm{NTU}$, TDS of $174 \mathrm{mg} / \mathrm{L}$, Conductivity of $240 \mu \mathrm{S} / \mathrm{cm}$ and DO of $6.6 \mathrm{mg} / \mathrm{L}$ (Table 1 ).

Table 1. Effect of coagulant dosage on water properties

\begin{tabular}{ccccc}
\hline Dosage (g/L) & Turbidity (NTU) & TDS (mg/L) & $\begin{array}{c}\text { Conductivity } \\
(\mu \mathrm{S} / \mathrm{cm})\end{array}$ & DO (mg/L) \\
\hline $\begin{array}{c}0.00 \text { (before } \\
\text { treatment) }\end{array}$ & 18.4 & 174 & 240 & 6.6 \\
0.03 & 4.9 & 180 & 260 & 4.6 \\
0.05 & 5.04 & 185 & 260 & 4.6 \\
0.1 & 6.07 & 188 & 260 & 4.7 \\
0.2 & 8.62 & 189 & 260 & 4.8 \\
0.3 & 11.5 & 190 & 260 & 5.0 \\
0.4 & 16.8 & 205 & 280 & 5.3 \\
\hline
\end{tabular}

\subsection{EFFECT OF CoAgulant DOSAGE ON TURBIDITY}

The effect varying the doses of MO $(0.03-0.4 \mathrm{~g} / \mathrm{L})$ on the low turbid water sample shows that at a dose of $0.4 \mathrm{~g}$, the turbidity reduced an initial value of 18.4 to $16.8 \mathrm{NTU}$, while at a dose of $0.03 \mathrm{~g}$ the turbidity reduced to $4.9 \mathrm{NTU}$. With respect to the permissible limit of 5NTU by WHO, the optimum dose of the coagulant for turbidity removal was $0.03 \mathrm{~g} / \mathrm{L}$. As reported by WHO (2006), MO's turbidity-lowering process is mostly based on seed proteins. The lowest dose of the coagulant was more effective in reducing the turbidity because the raw water contained little number of dispersed particles.

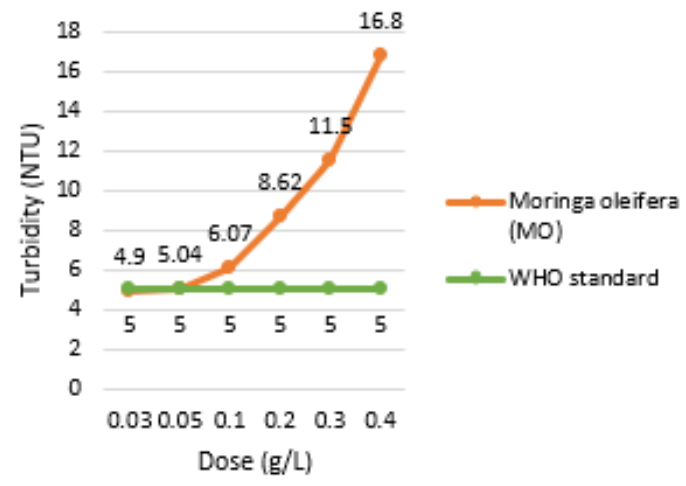

Fig. 1: Effect of coagulant dosage on Turbidity.

\subsection{Effect of Coagulant Dosage on Dissolved OXYGEN}

The DO value of the raw water sample was $6.6 \mathrm{mg} / \mathrm{L}$ before treatment, this value increased from $4.6 \mathrm{mg} / \mathrm{L}$ when a dose of $0.03 \mathrm{~g} / \mathrm{L}$ was used to $5 \mathrm{mg} / \mathrm{L}$ at $0.3 \mathrm{~g} / \mathrm{L}$ and finally to $5.3 \mathrm{mg} / \mathrm{L}$ at a dose of $0.4 \mathrm{~g} / \mathrm{L}$ (Figure 2). The 
obtained optimum dose that improved the DO to the recommended $\mathrm{WHO}$ value $(5 \mathrm{mg} / \mathrm{L})$ was $0.3 \mathrm{~g} / \mathrm{L}$.

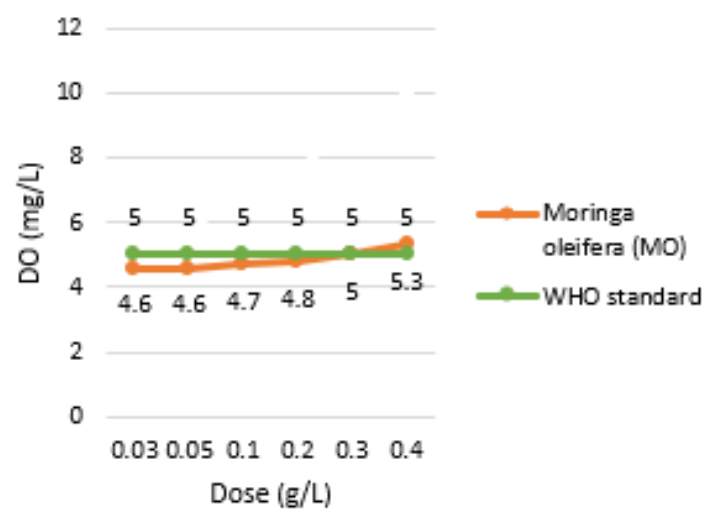

Fig. 2: Effect of coagulant dosage on DO

\subsection{EfFect of CoAgulant Dosage on Conductivity}

The initial conductivity value was $240 \mu \mathrm{S} / \mathrm{cm}$. After dosing, the conductivity of the treated water sample increased from $240 \mu \mathrm{S} / \mathrm{cm}$ to $280 \mu \mathrm{S} / \mathrm{cm}$. Although the coagulant added increased the value of conductivity by $17 \%$, it is still within the permissible limit. Increasing the coagulant dosage in the solution led to an increase in conductivity, this is owned to the formation of ions in the water samples during the coagulation process. Figure 3 shows the obtained results after each dosage.

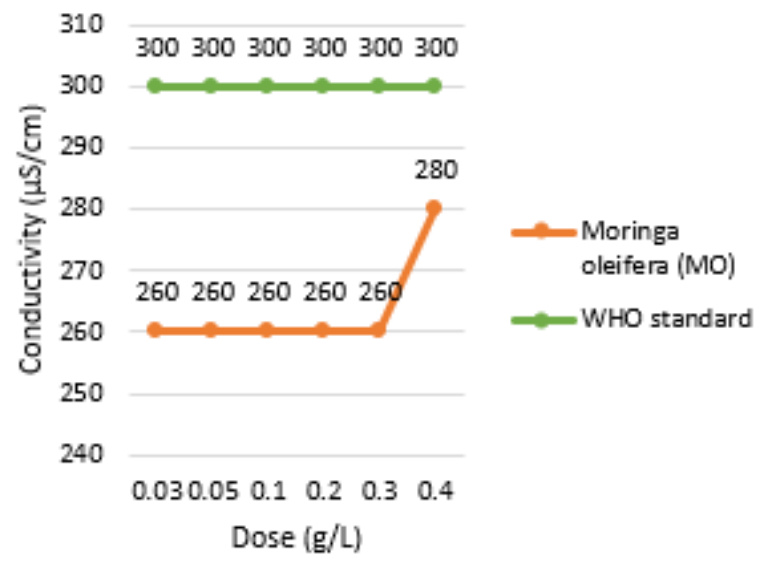

Fig. 3: Effect of coagulant dosage on Conductivity

\subsection{EfFect OF CoAgulant Dosage ON TOtal DISSOLVED SOLIDS (TDS)}

The initial TDS value of the raw water was $174 \mathrm{mg} / \mathrm{L}$. After treating with a dose ranging from $0.03 \mathrm{~g} / \mathrm{L}$ to $0.4 \mathrm{~g} / \mathrm{L}$, the TDS of the water samples increased from $180 \mathrm{mg} / \mathrm{L}$ at a dose of $0.03 \mathrm{~g}$ to $205 \mathrm{mg} / \mathrm{L}$ at a dose of $0.4 \mathrm{~g}$, which is within the preferred range of WHO standard $(<300 \mathrm{mg} / \mathrm{L})$ as seen in Figure 4.

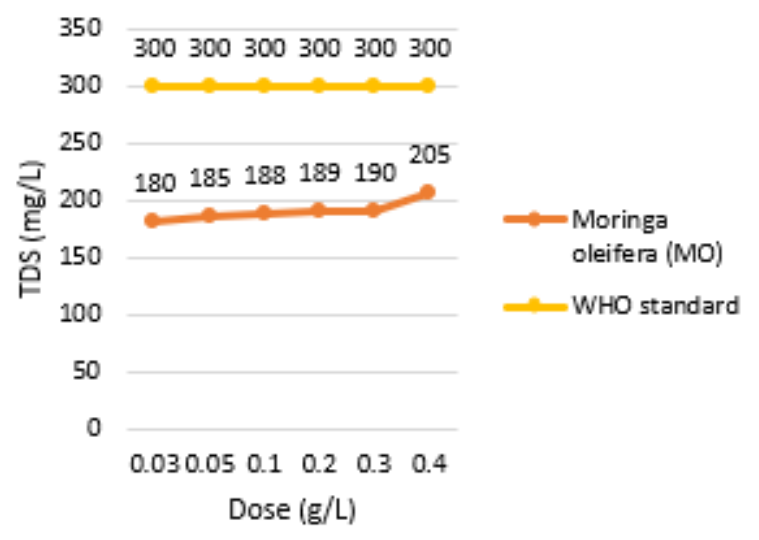

Fig. 4: Effect of coagulant dosage on TDS.

\section{Conclusion}

From the results obtained from the research, Moringa oleifera is an effective coagulant in the treatment of low turbid water. This agrees with the results obtained from other research works (Tunggolou and Payus, 2017; Ali, et al., 2009). Therefore, a strong recommendation is made for the use of the right quantity of Moringa oleifera in the treatment of low turbid water at household level.

\section{ACKNOWLEDGMENT}

The authors wish to thank Engr. Olaoye Peter for his support in carrying out the laboratory analysis.

\section{REFERENCES}

Akshaya, K.V., Rajesh, R.D., \& Puspendu, B. (2012). A review on chemical coagulation/flocculation technologies. Journal of Environmental Management, 93, 154 - 168.

Ali, E.N., Muyibi, S.A., Salleh, H.M., Salleh, M.R., \& Alam, Z. (2009). Moringa Oleifera Seeds as Natural Coagulant for Water Treatment. Hurghada, Egypt: International Water Technology Conference.

Amagloh, F.K., \& Benang, A. (2009). Effectiveness of Moringa Oleifera Seed as Coagulant for Water Purification. African Journal of Agricultural Resources, 4(2), 119-123.

Bhuptawat, H., Folkard, G.K., \& Chaudhari, S. (2007). Innovative physico-chemical treatment of wastewater incorporating Moringa oleifera seed coagulant. Journal of Hazardous Materials, 142(1-2), 477 - 482.

Environmental Protection Agency (2001). Parameters of Water Quality: Interpretation and Standards, Ireland.: Environmental Protection Agency.

Ezeh, E., Okeke, O., Nwosu, D., \& Okeakpu, B. (2017). Effects of pH, Dosage, Temperature and Mixing Speed on The Efficiency of Watermelon Seed in Removing the Turbidity and Colour of Atabong River, Awka-Ibom State, Nigeria. International Journal of Advanced Engineering, Management and Science (IJAEMS), 3(5), 427 - 434.

Gidde, R. (2011). Study of Moringa oleifera Extracts in Water Treatment, Department of Biological Sciences, ABU Zaria: (Unpublished Industrial Project Report).

Jahn, S.A. (1988). Using Moringa Oleifera seeds as coagulant in developing countries. J.A.W.W.A, 43-50.

Jain, M. (2010). Status of household water Treatment and Safe Storage in 45 Countries and a Case Study in Northern India.

Leiw, A.G., Noor, M.J., Muyibi, S.A., \& Fugara, A.M. (2006). Surface water clarification using Moringa oleifera seeds. International Journal of Environmental Studies, 63(2), 211 - 219.

Malla, B., Malla, R., \& Ramaraju, B.A. (2014). Physicochemical 
Characteristics of River Water and its Treatment Technology Using Moringa Seeds as a Coagulant. 4(5).

Mbaeze, M.C., Agbazue, V.E., \& Orjioke, N.M. (2017). Comparative Assessment of Performance of Aluminium Sulphate (Alum) and Ferrous Sulphate as Coagulants in Water Treatment. Mod Chem Appl. doi:10.4172/2329-6798.1000233

Moramudaii, M.A., \& Fernando, P. (2001). Use of seeds of Moringa oleifera to clarify turbid waters and wastewaters, Vidyodaya J. of Sci. 10, 167-182.

Muyibi, S.A., Salleh, H.M., Salleh, R.M., \& Gombak, J. (2003). Moringa Oleifera Seeds as Natural Coagulant for Water Treatment. Water Technology, 13, 163-168.

Muyibi, S.A., Ali, E.N., \& Salleh, H.M. (2009) 'Moringa oleifera seeds as natural coagulant for water treatment', Thirteenth International Water Technology Conference, 13(2), 1-10.

Raji, Y. O., Abubakar, L., Giwa, S.O., \& Giwa, A. (2015). Assessment of Coagulation Efficiency of Okra Seed Extract for Surface Water Treatment. International Journal of Scientific \& Engineering Research, 6(2), 719 - 725.

Tunggolou, J., \& Payus, C. (2017). Application of Moringa oleifera plant as water purifier for drinking water purposes. Journal for Environmental Science Technology. 10, 268-275.

World Health Organization, WHO. (2006). Weekly Epidemiological Record, 16(81), 145-164. 